\title{
INTERCULTURAL COMMUNICATION IN THE TRANSLATION OF HISTORY TEXTS
}

\author{
Prof. Rita Scotti Jurić, PhD \\ e-mail: rscotti@ffpu.hr \\ Department of language studies in Italian \\ "Juraj Dobrila" University in Pula (Croatia) \\ Sarah Zancovich, BA \\ Department of language studies in Italian \\ "Juraj Dobrila" University in Pula (Croatia)
}

\section{Introduction}

The majority of today's translations are translations of technical texts. This specific language field has been given diverse names, which are not always interchangeable, such as lingue speciali (Cortellazzo 1990), linguaggi specialistici (Gotti 1991), microlingue (Balboni 2000), etc. Over a long period of time, the learning of special languages used to be concerned almost exclusively with the acquisition of technical vocabulary, whereas today linguistic studies tend to focus on the discourse features of a text, in which language choices depend on pragmatic factors (the kind of addressee, their level of knowledge of the topic), as well as on the terminological and conceptual correctness. Besides the "horizontal dimension" of special languages, which refers to the topics being discussed, there is also a "vertical dimension", which reflects sociologic and pragmatic aspects (Cortelazzo, 1990). In this way, the opposition between the clarity and monoreferentiality of the technical text and the ambiguity of fiction ceases to exist, still confusing "ambiguity" with "polysemy". On the other hand, the pure technical-scientific text, written by and for experts, is easily recognizable for its semantic unambiguousness and the tendency to universality. When moving from specialised levels to diffusion, or when dealing with special "low-density" (Cortese, 1996, Garzone, Viezzi, 2001), "mid-binding" (Sabatini, 1990) micro-languages, since they are closer to common language, the presumed clarity turns out to be an illusion.

The language of politics and that of history texts are a prime example that can be used to prove that the terminological creation depends on cultural and linguistic contexts, which are not always comparable on inter-linguistic and inter-cultural level. This can be observed within special languages, which either use terms referring to contexts unknown by other languages or terms shared by both languages, but having different conceptual density. History texts offer interesting examples of these features, since they are a mixture of contents regarding history, arts, traditions, politics, 
institutions, etc: because of this, the translator of history texts acts as a real mediator between cultures. The complexity of such an activity is often undervalued, which leads to results that reveal both cultural and linguistic incompetence.

\section{The history text}

It is a well-known fact that notions like culture and tradition have been related to each other ever since the very beginnings of translation. A common focal point of the theoretical debate is the problem of cultural elements and the degree of their importance in the field of translation. Consequently, Newmark represents the notion of culture as "the way of life and its manifestations that are peculiar to a community that uses a particular language as its means of expression" (1988, 94). The intercultural conscience that springs from experience and awareness that there are diversities among the cultures, has occupied large areas of theoretical formulations in the field of translation. Moreover, the problem of untranslatable terms and phrases related to the "cultural" bond has always been an obstacle for translation theorists as well as for the translators themselves. To remedy this, Vermeer (2000) gives the translation a bicultural approach, since it is a process that necessarily requires cross-cultural transfer.

Other authors like Snell-Hornby will assume that the translation is not just a trans-coding of words and phrases from one language to another but " $a$ complex action in which someone provides information about a text under new functional, cultural and linguistic conditions and in a new situation" $(1995,46)$. Hatim and Mason talk about mediation between cultures in the translation activity: interaction is based on the factors of bilingual skills and factors of bi-cultural division which are intended to mediate for the "transfer of meaning" (1990, 223).

The history text, claims Sensini (2000), possesses some characteristics of narrative and literary texts, such as the structure of a tale and the description of events, the context, the presence of narrative events, etc. The language and stylistic-expressive choices in this type of text contrast to the bare language of merely technical texts. In both texts, episodes that have plots are dealt with, although the history text has more autonomous sequences and does not maintain the continuity of narration. Furthermore, both types share the temporal dimension, location and cultural context. Lacking context, there would be no content since the analysis in a history text starts from the real situation i.e. the context itself.

\section{Linguistic characteristics of the translation of the history text}

In this essay we have summarized the most interesting results of the translation of a history text from Croatian into Italian. ${ }^{1}$ The subject of the text is Nazi propaganda,

\footnotetext{
${ }^{1}$ The thesis Nacistička propaganda (Dunja Lendić, 2007), Faculty of Political Sciences, Zagreb, was translated by Sarah Zancovich. This paper does not contain the whole translation of the 
so in this way it also presents a part of the translation problems which is most meaningful as for intercultural and linguistic factors. The pleasure of translating, which evokes the peculiarities of a country and society at a particular historic moment, is based on the choice of different processes (loanword, calque, paraphrase, omission, use of cultural equivalents, hyperonyms, etc.), thanks to which there is the tendency to use specific translation strategies. Besides lexicon, the intercultural perspective involves other areas of language, like the choice of register and other linguistic strategies used. The translation difficulties identified while comparing the source text in Croatian and the target text in Italian were analysed, described, justified and classified according to the categories of acknowledged processes identified by the two authors Vinay and Dalbernet (1971), but also according to other principles. The stylistic comparison of the two authors introduces a formalised translation science which tends to describe a "product" by comparing the formal structures of the source and target text. This theory is valid when viewed in its practical function: to serve as a guideline for the translator with a procedural rigour.

The analysed history text is essentially clear, simple, flat, and linear, with an explicit and understandable language, without technical and specialised terms which make it impossible to understand the meaning. Obviously, the occurrence of terms that recall the historic and cultural dimension is strongly present within the words which are often left unchanged in their linguistic form in the target language, because of a semantic vacuum, so as to act like linguistic units independent from the context of the target language they are translated into. Depending on the purposes of translation, the cultural dimension of such lexical occurrences imposes diverse modes of transposition in the target language. Some words require the allocation of a semantic equivalent in a descriptive, connotative or simply generalizing mode. Even in the case of words and terms of intercultural communication, there are those which recall the institutional dimension and are very often left unchanged in the target language. This translation invariability therefore does not represent a problem for the translation, assuming that these expressions are accompanied in the intercultural communication of a given historic moment by a high degree of cultural identity which is common to the participants. This will allow a natural stabilization of these expressions in the target language system, without the need for cultural transfers.

We give an overview of the translation processes indicated by Vinay and Dalbernet (1971), knowing that we will not exhaust all the given possibilities of translation. The two Canadian authors note that the passage from one language into another occurs either due to direct translation or obliquel indirect translation. The three processes attributable to direct translation in which one can verify a match between the source language LP and the target language are the loanword, the calque and literal translation. Transposition, modulation, equivalence and adaptation can be attributed to indirect translation. They eliminate the distance between the two linguistic systems.

text since it is too large and would be superfluous for this essay that wants to deal with the problems encountered while translating history texts.

33 


\section{Direct translation}

A loanword (in Italian imprestito or prestito) is a foreign word that is used in the target language in the same form and with the same meaning that it has in the source language. The word is directly transferred to the target language (Mounin, 1965, 65), without any changes or translation, maintaining its original form. An example of this phenomenon is the German word Freikorps, which is already a loanword in the source language in which the original Croatian text was written, and, as a consequence, it becomes a loanword in Italian too. Its form, its spelling and its pronunciation have not changed. In Italian there is a translation for the German term Freikorps, and it is "Corpi Franchi", which refers to volunteers recruited for the first time in the Eighteenth century by Frederick II of Prussia, during the Seven Years' War. ${ }^{2}$ From that moment and until 1918, there were volunteers who would be recruited according to the needs. In 1918, there was a shift in the meaning of Freikorps: this word started to be used to denote extremely right-oriented paramilitary organizations that were formed in Germany after the Second World War. Today, when we use the word Freikorps, it is these organizations that we are referring to. So, to the expressions Corpi Franchi and Freikorps have been attached different historic meanings and due to this it would be wrong to translate the German word instead of keeping it as a loanword in Italian. It must also be said that the term "Corpi Franchi" is a calque of the German Fraikorps, which consists of frei (libero, franco) and Korps (corpo). ${ }^{3}$

Another interesting loanword is the German word Führer. The two examples are, to some extent, similar, because both loanwords, as a consequence of particular historic incidents, have acquired a definite meaning among people who use them out of the German borders. Actually, both words have the first meaning in the source language; however, as a loanword in the other languages, they refer to a particular form of police and a particular leader. If compared to the source language, in the target language both loanwords have undergone a restriction of meaning. The word Führer is a noun, but it also stands for "Adolf Hitler, dictator, head of state and chancellor of the Third Reich". This change of meaning and the historic facts that were the reason for it were so meaningful that nowadays in many German dictionaries, as one of the meanings of Führer, there is also Adolf Hitler's name to be found. The phonetic structure of the word reveals that it is a loanword, since it has characteristics that are unusual for the Italian language: the German noun is written with a capital letter, the letter $\ddot{u}$ and its pronunciation $[\mathrm{Y}]$ are not found in Italian or Croatian, and the metaphony in these languages is not expressed graphically, unlike in German, where it is marked by the Umlaut, which is another loanword from the German language (Trask, 1996, 221). ${ }^{4}$

${ }^{2}$ „Als Freikorps (frz. corps - Körper(schaft); aus lat. corpus - Körper) wurden zunächst freiwillige Einheiten bezeichnet. Heute beschreibt man damit eher paramilitärische Einheiten. Ursprünglich wurden Freikorps durch Friedrich II um die Zeit des siebenjährigen Krieges ausgehoben." (http://www.uni-protokolle.de/Lexikon/Freikorps.html)

${ }^{3}$ See the website: http://www.uni-protokolle.de/Lexikon/Freikorps.html (13 May 2009).

${ }^{4}$ The metaphony or Umlaut is a phonologic phenomenon that occurs when the sound of a vowel is modified under the influence of another vowel in an assimilation process. 
Another kind of loanword is the contraction of the German word Schutzstaffeln, which in Italian could be translated as "Reparti di difesa", "Squadre di difesa", "Squadre di protezione", but for which speakers prefer to use the German contraction "SS"; however, these letters are not pronounced as they are in the exit language [عs $\varepsilon s]$ : they are adapted to the Italian pronunciation and hence pronounced [' $E s s e$ ' $E s s e]$. This is a situation where the pronunciation of the loanword has been changed to fit the Italian phonetic system. Moreover, the acronyms that stand for the National Socialist Party, the NSDAP (Nationalsozialistische Deutsche Arbeiterpartei), and the secret services of the SS, the SD (Sicherheitsdienst) are to be regarded as loanwords because the original German terms are used and not the Italian or Croatian ones.

All the remarks made so far are also true for the already mentioned word Reich. Although the Italian translation of "Reich" is "regno" or "impero", using the German term will avoid any misunderstanding: by saying "Terzo Reich", "Treći Reich" or simply "Reich", it is clear which "kingdom" the speaker is referring to.

In the analysis of the text we have found and then applied translation strategies that are different from the loanword, i.e. the calque, which, unlike the direct loanword, is either never integrated or it is integrated only superficially (Beccaria, 1994, 121). As for the calque, the foreign word is translated using words that exist in the national language, but giving them a new meaning. Being actually a literally translated loanword, it is difficult to spot it because as for its form, spelling or pronunciation it does not differ from other words of the target language. An example of calque could be the Italian word "guerra-lampo", which reflects the German Blitzkrieg, made up of Blitz "lampo" and Krieg "guerra". For ordinary people it is difficult to spot a calque. Since in Italian there are compound nouns and since "guerra" and "lampo" are Italian words, this calque, and most of the others, can pass unnoticed.

Most of the calques that are to be noticed in the translated and analysed history text are literal translations of political and state structures, organizations and associations that are characteristic of Nazi Germany and unknown out of its borders. It is worth dwelling upon two untypical cases: expressions consisting of a loanword and a calque. The first case that is found in the Croatian text regards the official name of the service for public opinion founded by Napoleon, Press služba. This expression consists of an English loanword, press, and the calque of the English word service (which originally was part of this term), the Croatian služba. In Italian this concept can be expressed simply with a calque: "servizio stampa". The same procedure could have been applied in the translation from English into Croatian, having then "Služba za tisak". However, the loanword press is much more widespread in Croatian than it is in Italian, and it is frequently used in expressions such as "press konferencija", instead of "konferencija za novinare", or "izjava za presicu" instead of "priopćenje za tisak". Diachronic studies (Šiber, 1992, 11) remind us that the original term Service de presse was first formed in French and was first used by Napoleon: hence, the English expression is a calque of the original French. Calques have then spread to other languages, as it is the case of Croatian.

Another term formed of both a loanword and a calque is the name given to plays composed to celebrate the ascent and triumph of National Socialism, the thing-drammi. 
The word thing is a loanword from Old Norse and it denotes the government assembly of Germanic society, but it can also mean tribunal, meeting place, assembly, whereas the word "dramma" (in the Croatian text "drama") is the calque of the meaning that the German word Spiel has in the original expression Thingspiel.

As for real calques, we have to take into consideration those terms denoting political and state organizations that are translated into a language in which those structures are not known or are not called in the same manner. Since these structures are typical of the Third Reich, all names of ministries and chambers, both in the original Croatian and in the Italian translation, are calques of German nouns: "Ministarstvo propagande i narodne prosvjete", "Ministero per la propaganda e l'educazione popolare" (Reichsministerium für Volksaufklärung und Propaganda); "Ministarstvo za privredu i prehranu", "Ministero dell'agricoltura e l'alimentazione" (Ministerium für Landwirtschaft und Ernährung); "Ministarstvo prometa", "Ministero dei trasporti" (Ministerium für Verkehr); "Ministarstvo pošte”, „Ministero delle poste” (Ministerium für Post). The same procedure is valid for the translation, in Croatian as well as in Italian, of the various chambers that formed the Reichskulturkammer. The names of all the chambers are calques of German expressions: Reichsschriftkammer: "Državna komora za spisateljstvo" and "Camera per la letteratura del Reich"; Reichspressekammer: "Državna komora za tisak" and "Camera per la stampa del Reich"; Reichsfunkkammer: "Državna komora za radio" and "Camera per la radio del Reich"; Reichstheaterkammer: "Državna komora za kazalište" and "Camera per il teatro del Reich"; Reichsmusikkammer: "Državna komora za glazbu" and "Camera per la musica del Reich"; Reichskunstkammer; "Državna komora za likovnu umjetnost" and "Camera per le arti figurative del Reich"; Reichsfilmkammer: "Državna komora za film" and "Camera per il cinematografo del Reich". The same is true for various other organizations, unions, leagues, departments: the "Lega per i teatri all'aperto e per i teatri popolari" or "Savez za kazališta na otvorenom i narodna kazališta" and the "Lega di Combattimento per la cultura tedesca" or "Borbeni savez za njemačku kulturu", are calques of the German Reichsbund der deutschen Freilicht- und Volksschauspiel and Kampfbund für deutsche Kultur.

The situation is different when it comes to the Ministry of Foreign and Home Affairs because these administrative structures exist and have the same functions in all of the three countries. As a consequence, in this case, not only can the names of these ministries be translated literally, since in the three languages they consist of the same words, these structures do also exist in the three cultural contexts. Over many centuries, this function was defined more or less precisely and it was given many names: "segretariato di stato", "consiglio di stato". ${ }^{6}$ Hence, "Ministero degli Affari Esteri /

5 Thing: Gerichts- und Volksversammlung der alten Germanen, Volksvertretung in den nordischen Ländern (Das neue deutsche Wörterbuch für Schule und Beruf, 1996, Wilhelm Heyne Verlag, Munich, 914).

${ }^{6}$ The system of ministries first started to develop in France around the end of the fifteenth century when the number of councils increased, their functions became more specialized, and more and more non-noble members were invited to join in due to their legal, administrative and financial competences. (Guerracino, 1998, 456); however, it was only in 1626 that Cardinal Richelieu founded 
Ministero degli Interni", "Ministarstvo vanjskih poslova / Ministrastvo unutarnjih poslova" and Auswärtiges Amt / Ministerium des Inneren match both linguistically and socio-culturally.

Even if Croatian and Italian differ since the first is an analytical and the second a synthetical language, it is often possible to translate literally, word for word. Thus, in the sentence " $/ . . /$ jer je prednost filma kao instrumenta u službi propagande /.../" the word "instrument" can be translated with "strumento", which originates from the Latin word instruměntu(m), meaning tool, gadget, furnishings (Cortelazzo and Zolli, 2004, 1268) in both languages. If we continue translating this causal clause, we notice that one of the possible solutions can also be literal translation, so as to have: perché il vantaggio del film, quale strumento al servizio della propaganda, è /.../.

The term "predizborna kampanja" is translated literally, too: "campagna elettorale". This is possible because both meanings originate from the late Latin campannia $(m)$ and because of the adaptation of the meaning in the compound term: "period in which an activity takes place" (Cortelazzo and Zolli, 2004, 201), in this case elections.

Moreover, the syntactic structure subject-verb-object (Marinucci, 1996, 309) is characteristic of both languages; because of this, changes in the word order occur very rarely. One of the cases when the translator has to modify the word order in a sentence is when there is an adjective close to a possessive genitive, as it is in the example "vrata Goebbelsova ureda", where "Goebbelsova" is a possessive adjective and "ureda" is a possessive genitive (Silić, 1997, 17). In Italian, both words have the function of "complemento di specificazione" ("di Goebbels" and "dell'ufficio"), which denotes possession and belonging: it is here placed after the "complemento di specificazione esplicativo", so as to have "la porta dell'ufficio di Goebbels".

\section{Oblique translation}

There are cases, which are also quite frequent, when literal translation is not possible since languages do not always coincide in all their aspects and structures. In this case, Simone (2005) believes that we must start from the surface structure of the source language and through the analysis of its deep structure come to the deep structure of the target language. Finally, the last thing to do would be to trace the superficial structure of the target language. One of the processes that allows the oblique translation, i.e. not direct, is transposition. According to Mounin "it consists of substitution of one part of speech with another without changing the meaning of the phrase" $(1965,65)$. This technique includes the change of grammatical categories of words during translation through the shift of one element of the sentence, from the

the first ministry for foreign affairs (Berridge, 2004, 5). Anyway, a system of ministries was created in France not earlier than in 1791, when, after the revolution, the old administrative organs were replaced with new structures. See Ciapparoni, F., Cenni stroici sulla evoluzione dell'amministrazione pubblica in Italia, report held on 5 March 2004 at the Faculty of Law of the LUMSA. (http://vgci.it/Testi_scarica/REL._Ciapparoni.doc) 
grammatical category used in the source language, to a different grammatical category used in the target language. The majority of these shifts relate to changes of nouns into verbs and vice versa.

The translation of the direct object clause "oni koji su bili protiv toga" could be simply "di coloro che erano contro di ciò", but the phrase can be simplified by translating the clause with a single noun: "degli oppositori". The meaning remains the same and the change is that the clause in the target language is less complex than the one in the source language.

In the proposition: "propaganda je namjerno i plansko djelovanje na mnijenje $\mathrm{i}$ kontroliranje stavova", a part of the proposition is implemented during the translation. If "djelovanje" was translated as a noun, e.g. as "azione", it would not be possible to continue with the translation word for word and turn the sentence into "la propaganda è un'azione intenzionata e pianificata sull'opinione e sul controllo degli atteggiamenti", because it would seem incomplete unless a verb is added: "la propaganda è un' azione intenzionata e pianificata che agisce sull'opinione e sul controllo degli atteggiamenti". Instead of translating "djelovanje" with a noun we could use a corresponding noun-verb and simply get "la propaganda è l'agire intenzionale e pianificato sull'opinione e sul controllo degli atteggiamenti".

A slightly different case is that of the modulation process, which consists of transmitting the message of the original text by adopting a different perspective, a new point of view, as Mounin says (1965). Thus, during the translation of the sentence "isključenje je pogađalo cijeli kulturni spektar, od umjetnosti do zabave" which becomes passive, there is a change of subject into direct object and of the active verb into passive. In this way we have a sentence in which the prospective is opposite to the one in Croatian: "tutto lo spettro culturale, dall'arte al divertimento, avvertì l'impatto dell'esclusione".

One can speak of modulation even in the case of the translation of an adjective with the negation of its opposite. While retaining the message of the source text, it changes the attitude of what is alleged. Consequently, the attribute of the nominal predicate of the phrase in Croatian "ako su naše informacije točne" after applying the modulation process, becomes: "se le nostre informazioni non sono errate". Although the adjective "esatto" and the negation of its opposite "non errato" are synonyms, this modification becomes a modulation. Actually, the first case ("se le nostre informazioni sono esatte") as well as the second ("se le nostre informazioni non sono errate") are expressed with conditional clauses, for which the speaker is not sure of the realization or truth of their assertions. While in the first version the speaker seems to be surer and shows a direct relationship with the source of the information, the second solution is weaker and reinforces the doubt implied by the conditional construction. This last sentence seems to be set out to conceal the fear of the possibility that what has been said will not be achieved. There is then a change of the point of view due to modulation.

Another case of modulation, this time due to the change in word order in the sentence, is the one when the sentence in Croatian has a direct object on the first place and an active verb: "izložbu je otvorio Adolf Ziegler". This is not possible in Italian because whenever a sentence in Italian begins with a direct object, the verb has to be 
passive ("la mostre è stata aperta da Adolf Ziegler"). Consequently, the Croatian sentence where the direct object "izložbu", thanks to the accusative case, can be deployed without affecting the active aspect of the sentence, in Italian the sentence is subject to the modulation process and its value changes from active to passive. Wanting to maintain the active aspect of the proposition, it would be enough to place the direct object after the verb and put the subject in its regular position: "Adolf Ziegler aprì la mostra", but, since in the first five paragraphs of this chapter only the exhibition is being discussed, it is understandable that the noun "mostra", the topic of the chapter, should occupy the first place.

The process of equivalence, defined as the replacement of particular linguistic material, such as idiomatic expressions, proverbs, phraseology, phrasal expressions, was not often adopted during the translation of history texts. This could be because the phraseology used during the writing of the original text roughly corresponds in both languages, so there was not a perfect application of this process. Following Mounin's definition (1965), we can state that the terms found in the analysis of the history text are cases of semi-equivalence, since in the majority of the cases there were two types of situations: either in the source language there was a locution that was translated with a simple verb, or in the source language there was a verb whose meaning was turned into a message that is a locution or an idiomatic expression.

An example that comes close to a real case of equivalence is that of a Croatian saying "padali su otkazi" translated into Italian with "pioggia di licenziamenti". The message changes partially because in both cases dismissals are mentioned, but the second part of the saying is changed. In this case, in both languages, we talk about expressions of saying: the meaning remains the same, but the message, the linguistic material, is not completely changed.

It is likely that the contact and cultural environment of the two languages/cultures do so that many idioms in the text have no need to seek for equivalence of any kind, since their counetrparts are identical. So, "igrati ulogu" literally corresponds to "interpretare un ruolo", "ući pod kožu" in Italian also corresponds to "entrare sotto la pelle", "budno oko" can be both translated "sguardo attento" as well as "occhio attento", "ispiranje mozgova" is "lavaggio del cervello", "osjetiti na svojoj koži" again remains the same in the target language "provare sulla propria pelle". Obviously, there are cases where you need to find an equivalent in the target language since it is impossible to find identical linguistic situations. Hence, the meaning of the Croatian message "imati i ovce i novce" is formed in Italian with different linguistic material that maintains the same meaning "salvare capra e cavoli".

We must point out that not all the authors define equivalence in the same way so consequently there might be discrepancies in the meaning of the terminology used. According to Peirce $(1931,1935,1958)$, equivalence is something subjective, it is valid "only in some aspects" or "with some capacity" and has no absolute value but ephemeral. Peirce assumes equivalent as "correspondent". Even according to Catford's opinion (1965), textual equivalence is used when there is no formal correspondence, which happens very often because formal correspondence is almost always approximate. 
If in the comparison of the original text with the translation rare and incomplete examples of equivalence emerge, examples of adaptation are even rarer and in this particular translation seem to be rather wanted than needed and spontaneous. Adaptation is the extreme limit of translation, the process by which one tends to translate a roughly similar situation which is untranslatable with another more or less similar one. Mounin says $(1965,65)$ "this way a term drawn from the English language of baseball can be translated with a French term suggested by the Tour the France". The proximity, contact and the exchange between the Italian and Croatian language, together with their cultures which are similar in many linguistic and life situations, have made so that there is no need of such "cultural distances". In a technical text where concepts which are unknown must be described and explained, it is inappropriate to use the adjustment because a normal and granted situation in the source language, but unknown to the speakers of the target language, cannot be explained with a typical example in the target language, but will need to be described and explained to the reader who does not know its meaning. During the translation of the history text, no examples of this type appeared. For information, we will mention the Italian idiomatic expression "andare in brodo di giuggiole", used to express a state of great satisfaction and referred to a jujube soup, which is considered a great and rare delicacy. In Croatian, no expressions that contain or refer to jujube are used, let alone to express mood. Any linguistic situation containing a reference to jujube would not be understood in the great part of the country and it would have to be changed by mentioning proverbially appreciated food, typical of the inland, e.g. "ići grlom u jagode", "upala mu sjekira u med". Another case is that of the worship of the "Our Lady of the Stone Gate" in Zagreb. Using references to this cult, in the translation of a technical text (say of cultural anthropology), it could be translated with a similar case of the veneration of another Christian personality, typical of the country of the target language, but explaining and describing the characteristics and the history of the cult in its original context.

\section{Other changes}

Besides this first classification that includes the procedures applied to translation and proposed by Vinay and Dalbernet (1971), the comparison of the two texts brings up other changes that were made by the translator. The choice of the most suitable among all the expressive possibilities is also due to two more linguistic factors: transparency and generality or narrowness of the translated term.

The transparency of the term (Casadei, 1999) can often simplify and make its translation easier. This is usually the case of compound nouns, in which the meaning is given by the combination of the two words. A compound word is not arbitrary anymore; it is motivated and it is easier to grasp its meaning by looking at the words that it consists of (Simone, 2005). Sometimes, however, the transparency of the word does not facilitate its translation because its correspondent in the target language does not consist of the same elements. So, in the Croatian compound word "uskogrudnost", we can recognize the elements "usko", meaning "narrow", and "grudi", which means "breast". 
The meaning of the compound word consisting of these two elements should be translated in Italian as "ristrettezza di petto", "ristrettezza di cuore", "ristrettezza d'animo". However, in Italian, instead of a compound word, the locution "viltà d'animo" is used, an expression that does not fit in the context in which the Croatian word appeared: "javni jezik diktature podupirao je odsutnost kritike i uskogrudnost". In this context, it is better to translate "uskogrudnost" with "tendenziosità". The transparency of the Croatian word "izjednačiti" is due to the verbal prefix $i z-$, which means the action of fulfilling something, of bringing something to an end, and to the adjective "jednako", which means "the same". Following the direction shown by the expression obtained, "rendere uguale", we get to the word we needed, the synonym "uniformare".

While translating, there are cases when the word to be translated and its counterpart in the other language do not match perfectly since one of the terms can either be more specific or more general. Because of this, it is possible to have more translations of the same word. Let us consider the following instance: "Hitler je redovito objavljivao svoje poglede na umjetnost". In this sentence, the word "poglede" does not have, in this context, a perfect match in Italian and it is general enough to be translated both with "opinioni" and with "punti di vista". Hence, both possibilities are valid: "Hitler manifestava regolarmente le sue opinioni sull'arte" as well as "Hitler manifestava regolarmente i suoi punti di vista sull'arte".

The generality of the meaning of a word implies a multiplicity of its meanings, too, i.e. a variety of different meanings that the word has in the two languages. A word can have one single meaning in the source language, i.e. it can be very restricted, or narrow, whereas its translation in the target language can have many more meanings. An example to explain this phenomenon can be the word limes, of Latin origin: in Croatian, this word means the limit of the mathematical function as well as the threshold of sensitive perceptions, but also, in a wider sense, a border or even, more specifically, the border of the Roman Empire, marked by towers, fortresses and walls ${ }^{7}$; in Italian, the same word does only have this last meaning, while to denote all the other concepts the word "limite" is used.

If the term of the target language is more frequent than the one of the source language, i.e. if it has more meanings, it will be possible to choose among various options, among more words with restricted meaning. In the sentence "velika je pažnja posvećena izrazu i pozi", the word "poza" can be translated with the Italian "posa", which has more meanings than its Croatian match: it is more general and can mean "pose", "position", but also "posture". A similar case is the one of the word "izrazit" within the expression "izrazit profil", which in Italian can assume the following meanings: "marcato", "tipico", "specifico", "accentuato", "espressivo". The word "slika", too, included in the sentence "ni na jednoj slici nije bilo pokušaja da se Hitler prikaže kao stvarna osoba", could be translated with "fotografia", "ritratto", "immagine", "dipinto". These examples show that because of its generality and multiplicity of meanings the same word has diverse specific meanings.

7 “Limes”, Hrvatski enciklopedijski rječnik, vol. 5, Novi Liber, Zagreb, 2004, 367.

41 


\section{Conclusion}

The theories used to analyse the role of inter-cultural elements in the translation of history texts (Vinay and Dalbernet, 1971; Casadei, 1999) observe the underlying rules of these skills, translating within objective criteria that can be applied with rigour, so as to be able to call translation a science. It is clear that a good translator cannot simply stick to the norms listed by a few authors: translation is not concerned with the transfer of languages, but with that of texts, which imply extra-linguistic and extratextual factors (not taken into consideration by linguistics) that are fundamental for the construction of the meaning. It is necessary to research into the concept of culture, which is fundamental in history texts and which is both relative and universal. If we think of culture as being characteristic of an autonomous language community, then in many cases there are cultural areas that transcend the borders between languages, aiming at a global culture with the same customs and ideologies. Hence, the fact that a text is translatable appears to be one of the characteristics of language and this is also the basis of the semantic process. In this case, translation becomes a creative means that paves the way to intertextuality and the mutual enrichment of cultures, according to Levý: "The translator enriches the national literature of their country with new linguistic values, not only by creating new means of expression (neologisms), but also by assimilating in his environment words and phrases of other countries (exoticisms)." (Levý, 1963, 115).

Theories formulated upon concrete translation elements imply that the cultural link is not merely the basis of the translation process, but it also becomes one of its problems. In translation studies, the element called "culture", according to Vinay and Darelnet, ${ }^{8}$ accounts for at least two basic functions: one is representative, because it aims at representing the terms giving them only one denomination, symbolic, in the diverse languages; the other one is communicative, because it tries to transfer the concepts from one language into the other using a "direct translation" approach which thus takes the characteristics of "literal translation" (2000, 84-93).

\section{References}

BALBONI, P., 2000, Le microlingue scientifico-professionali, UTET, Torino.

BERRIDGE, G. R., 2004, Diplomacija, Politička misao, Zagreb.

CALVI, M. V., 2003, La traduzione nell'insegnamento della lingua e nello studio dei linguaggi specialistici, in "Tradurre dallo spagnolo", Study day, Milan 28 February 2003, http:// www.ledonline.it/e-seminars/tradurredallospagnolo.html

CASADEI, F., 1999, Significato ed esperienza. Linguaggio, cognizione, realtà, Semantica. Teorie, tendenze e problemi contemporanei (edited by) Daniele Gambarara, Carocci, Rome.

CATFORD, J. C., 1965, A Linguistic Theory of Translation, Oxford University Press, London.

${ }^{8}$ See also other authors, e.g. Scollon and Wong Scollon, 1995.

42 
CORTELAZZO, M., ZOLLI, P., 2004, Dizionario etimologico della lingua italiana, Zanichelli, Bologna.

CORTELAZZO, M., 1990, Lingue speciali. La dimensione verticale, UNIPRESS, Padua.

CORTESE, G., 1996, Tradurre i linguaggi settoriali, (edited by), Edizioni Libreria Cortina, Turin.

DAS NEUE DEUTSCHE WÖRTERBUCH FÜR SCHULE UND BERUF, 1996, Wilhelm Heyne Verlag, Munich.

GARZONE, G., VIEZZI, M., 2001, Comunicazione specialistica $e$ interpretazione di conferenza, Edizioni Università di Trieste, Trieste.

GOTTI, M., 1991, I linguaggi specialistici, La Nuova Italia, Florence.

GUARRACINO S., 1998, L'età medievale e moderna. Dalla crisi del Trecento allo Stato assoluto, Mondadori, Milan.

HATIM, B., MASON, I., 1990, Discourse and the Translator, Longman, London.

HRVATSKI ENCIKLOPEDIJSKI RJEČNIK, 2004, vol. 5., Novi Liber, Zagreb.

LEVÝ, J., 1963, Iskusstvo perevoda, Progress, Moscow, Italian translation 1992, I problemi estetici del tradurre, in „Testo a fronte“, no.7, Guerini, Milan.

MARINUCCI, M., 1996, La lingua italiana, Mondadori, Milan.

MOUNIN, G., 1965, Teoria e storia della traduzione, Einaudi, Turin.

NEWMARK, P., 1988, A Textbook of Translation, Prentice International, Hertfordshire.

PEIRCE, C. S., 1931, 1935, 1958, The Collected Papers of Charles Sanders Peirce, vol. 1-6 (edited by) Hartshorne, C., Weiss, P., vol. 7-8 (edited by) Burks, A. W., Harvard University Press, Cambridge.

SABATINI, F., 1990, La comunicazione e gli usi della lingua, Loescher, Turin.

SCOLLON, R., WONG, SCOLLON, S., 1995, Intercultural Communication, Oxford UK \& Cambridge USA, Blackwell.

SENSINI, M., 2000, Il sistema della lingua, Arnoldo Mondadori, Milan.

ŠIBER, I., 1992, Politička propaganda i politički marketing, Alinea, Zagreb.

SILIĆ, J., 1997, Hrvatski jezik 2, Školska knjiga, Zagreb.

SIMONE, R., 2005, Fondamenti di linguistica, Laterza, Bari- Rome.

SNELL-HORNBY, M., 1995, Translation Studies: An Integrated Approach, John Benjamins.

TRASK, R. L., 1996, Dictionary of Phonetics and Phonology, Routledge, London.

VERMEER, H. J., 2000, Skopos and Commission in Translational Activity, in Venuti, L., (edited by), The Translation Studies Reader, Routledge, London, 221-232.

VINAY, J. P., DALBERNET, J. 1971, Stilistique comparée du français et de l'anglais, Didier, Paris. 
Metodički obzori 9; vol. 5(2010)1

Prethodno priopćenje

UDK: $81 ' 25$

Primljeno: 18. 10. 2009.

\section{INTERKULTURALNA KOMUNIKACIJA U PREVOĐENJU POVIJESNIH TEKSTOVA}

Prof. dr. sc. Rita Scotti Jurić Sveučilište Jurja Dobrile u Puli, Odjel za studij na talijanskom jeziku e-mail: rscotti@ffpu.hr

Sarah Zancovich, diplomatica Sveučilište Jurja Dobrile u Puli, Odjel za studij na talijanskom jeziku

\section{S a žetak}

U prevođenju tehničkih tekstova uporabljuju se različiti nazivi kao posebni govori, mikrojezici struke, itd. Usvajanje takvih govora ne uključuje samo poznavanje stručnog vokabulara, već i diskurzivnih svojstava teksta u kojima kulturni i jezični sustavi određuju izbor terminologije, a istovremeno nisu uvijek usporedivi na međujezičnom i međukulturnom nivou. Teorijski naputci, verificirani na konkretnim primjerima iz prevoditeljske prakse, svjedoče da je kulturološka spona (elementne samo temeljprevoditeljskog procesa, već i svojevrsni problem).Studije o prevođenju (Vinay e Darbelnet, 1971; Scollon, Wong Scollon, 1995) razmatraju pojam kult kroz dva temeljna funkcionalna gledišta: jedno rep odrediti jedinstveno denom pojma koji će postati simboličan i za druge jezike, a drugokomunikativa pojmovi iz jednog jezi izravnog pristupa u prevođenju (direct translation) značajke doslovnog prijevoda (literal translation).Clanak nudi analizu povijesnog teksta u kojemu se ukrštavaju umjetnost, tradicije, politika, institucije, te se ukazuje na to da je uloga prevođenja svojevrsno interkulturalno posredovanjeDa bi prijevod povijesnih tekstova bio što vjerodostojniji,naya i Dalberneta (1971), svjesne da se time ne iscrpljuju sve postojeće strategije prevođenja. Spomenuti kanadski autori primjećuju da prijelaz drugi može biti izravno (direktno, a time doslovno) ili koso (poprečno ili nedoslovno). Tri postupka koja se mogu pripisati izravnom pr, kalk i doslovni prijevod. Kosi prijevod se ostvaruje u transpoziciji, modulaciji, ekvivalenciji i adaptaciji, procesi koji uklanjaju postojeću udaljenost između dva jezična sustava.

Ključne riječi: interkulturalna komunikacija, direktno (izravno) i poprečno (koso) prevođenje, transpozicija, ekvivalencija, modulacija, prilagodba. 